\title{
Pengembangan sumber daya manusia sebagai faktor yang mempengaruhi produktivitas kerja
}

\author{
(The development of human resources as a factor affecting work \\ productivity)
}

\author{
Yohan Dwi Putra', A. Sobandi ${ }^{2 *}$ \\ 1,2Program Studi Pendidikan Manajemen Perkantoran \\ Fakultas Pendidikan Ekonomi dan Bisnis, Universitas Pendidikan Indonesia \\ JI. Dr. Setiabudhi, No. 229 Bandung, Jawa Barat Indonesia \\ Email: ade@upi.edu
}

\begin{abstract}
ABSTRAK
Pengembangan sumber daya manusia adalah faktor yang telah terbukti secara empiris memiliki pengaruh yang signifikan terhadap produktivitas kerja. Artikel ini membahas hasil penelitian tentang pengaruh antara dua variabel tersebut. Penelitian ini dilakukan dengan menggunakan metode explanatory survey, dimana data dikumpulkan dengan menggunakan angket model skala rating scale yang diberikan kepada responden sejumlah 57 orang pegawai Dinas Pendidikan Kota Bandung yang menjadi objek penelitian. Analisis deskriptif yang dilakukan menunjukkan bahwa pengembangan sumber daya manusia berada pada kategori efektif sedangkan produktivitas kerja berada pada kategori sedang. Analisis menunjukkan bahwa pengembangan sumber daya manusia memiliki pengaruh yang positif dan signifikan terhadap produktivitas kerja. Untuk meningkatkan produktivitas kerja, pegawai harus meningkatkan pengetahuan, keterampilan dan motivasi sehingga produktivitas kerja dapat diperoleh secara optimal.
\end{abstract}

Kata Kunci: pengembangan sumber daya manusia; produktivitas kerja

\begin{abstract}
Human resource development is a factor that has been proven empirically having a significant effect on work productivity. This article discusses the results of research on the influences between two variables. This research was conducted by using explanatory survey method, where the data was collected by using questionnaire scale model, it was given to respondents, 57 employees of Bandung City Education Office. The descriptive analysis shows that the development of human resources are in the effective category, while work productivity is in the medium category. The analysis shows that the development of human resources has a positive and significant impact on work productivity. To improve work productivity, employees must increase knowledge, skills, and motivation so that their work productivity can be optimal.
\end{abstract}

Keywords: human resource development; productiviy

Received: Agustus 2018, Revision: November 2018, Published: Januari 2019 


\section{PENDAHULUAN}

Salah satu masalah yang menarik untuk dikaji saat ini adalah mengenai rendahnya produktivitas kerja. Produktivitas merupakan salah satu hal penting yang perlu diperhatikan setiap organisasi. Produktivitas kerja yang rendah akan mempengaruhi mutu organisasi, karena produktivitas kerja digunakan untuk mengukur hasil kualitas sumber daya yang dimiliki organisasi pada suatu pekerjaan tertentu sekaligus untuk mengetahui tingkat kesesuaian dengan kebutuhan sumber daya manusia. Dinas Pendidikan Kota Bandung adalah salah satu instansi pemerintah yang bertugas menyelenggarakan sebagian kewenangan di bidang pendidikan. Dinas Pendidikan Kota Bandung sebagai organisasi yang memiliki kontribusi langsung pada masyarakat, mewujudkan tujuan yang telah ditetapkan dengan hasil yang baik. Akan tetapi masih ada hasil dari pekerjaan pegawai yang masih rendah sehingga masih kurang efektif dan efisien, produktivitas kerja di Dinas Pendidikan Kota Bandung khususnya pada saat ini masih belum optimal.

Berdasarkan data yang diperoleh terdapat penurunan produktivitas, produktivitas kerja pada tahun 2014 dengan kegiatan membuat surat tugas bagi tenaga pendidik dalam rangka peningkatan mutu pembelajaran tidak mencapai target yang ditetapkan dengan persentase tugas yang tidak tercapai sebesar 9,75\%, sedangkan pada tahun 2015 sebesar 6,59\% dan pada tahun 2016 sebesar 8,25\%. Pada kegiatan mengarsipkan surat keluar pada tahun 2014 persentase tugas yang tidak tercapai sebesar 12,5\%, pada tahun 2015 sebesar 6,97\%, dan pada tahun 2016 sebesar 5\%. Pada kegiatan memproses administrasi usulan mutasi tenaga pendidik, persentase tugas yang tidak tercapai sebesar $20 \%$, pada tahun 2015 sebesar 22,2\% dan pada tahun 2016 sebesar 35,5\%. Pada kegiatan membuat konsep surat keluar pada tahun 2014, persentase tugas yang tidak tercapai pada tahun 2014 sebesar 3,75\%, pada tahun 2015 sebesar 9,89\% dan pada tahun 2016 sebesar $6,28 \%$. Pada kegiatan mengelola administrasi yang mendapat beasiswa prestasi, persentase tugas yang tidak tercapai pada tahun 2014 sebesar 22,9\%, pada tahun 2015 sebesar $16 \%$ dan pada tahun 2016 sebesar $14,8 \%$.

Pertanyaan yang segera muncul adalah mengapa produktivitas kerja belum optimal? Bertepatan dengan fenomena tersebut menurut R.Smith (Richard dan Elwood, 2001 hlm. 5) menyatakan bahwa pengembangan sumber daya manusia terdiri dari program dan kegiatan, instruksional dan/atau individu secara positif mempengaruhi perkembangan individu dan produktivitas dan keuntungan organisasi. Dapat disimpulkan bahwa faktor pengembangan sumber daya manusia diduga mempengaruhi produktivitas kerja, sehingga dijadikan kajian dalam penelitian ini.

Belum optimalnya produktivitas kerja selama ini sebagaimana ditunjukan oleh fenomen-fenomena yang terjadi merupakan suatu masalah. Apabila hal ini terus dibiarkan, tentu akan berdampak buruk bagi organisasi maupun pegawai itu sendiri terlebih karena produkitivitas kerja akan secara langsung memberikan pengaruh kepada pencapaian tujuan organisasi dan penurunan rasa kepecayaan dari masyarakat.

\section{TINJAUAN PUSTAKA}

\section{Pengembangan Sumber Daya Manusia}

Pengembangan adalah suatu proses untuk memperoleh keterampilan dan pengetahuan agar berhasil dalam melaksanakan suatu pekerjaan dan tugas-tugas di masa sekarang dan yang akan datang. Pengembangan adalah suatu usaha untuk meningkatkan kemampuan teknis, teoritis, konseptual, dan moral pegawai sesuai dengan kebutuhan pekerjaan/jabatan melalui pendidikan dan pelatihan (Hasibuan, $2007 \mathrm{hlm}$. 69). Menurut 
Sumarsono (2003 hlm. 4) sumber daya manusia mengandung dua pengertian. Pertama, sumber daya manusia mengandung pengertian usaha kerja atau jasa yang dapat diberikan dalam proses produksi. Dalam hal lain sumber daya manusia mencerminkan kualitas usaha yang diberikan oleh seseorang dalam waktu tertentu untuk menghasilkan barang atau jasa. Pengertian kedua, sumber daya manusia menyangkut manusia yang mampu bekerja untuk memberikan jasa atau usaha kerja tersebut. Mampu bekerja berarti mampu melakukan kegiatan yang mempunyai kegiatan ekonomis, yaitu bahwa kegiatan tersebut menghasilkan barang atau jasa untuk memenuhi kebutuhan atau masyarakat.

Pengembangan (development) mewakili usaha-usaha meningkatkan kemampuan para karyawan untuk menangani beraneka tugas dan untuk meningkatkan kapabilitas di luar kapabilitas yang dibutuhkan oleh pekerjaan saat ini (Mathis dan Jackson, $2006 \mathrm{hlm}$. 350). Rowley dan Jackson (2012 hlm. 88) menjelaskan bahwa pengembangan sumber daya manusia adalah sebuah proses yang dilakukan untuk mengembangkan pengetahuan, keahlian, dan kemampuan pekerja, demikian juga dengan kompetensikompetensi yang dikembangkan melalui pelatihan dan pengembangan, pembelajaran organisasi, manajemen kepemimpinan, dan manajemen pengetahuan untuk kepentingan peningkatan kinerja.

Dalam arti yang lebih luas, pengembangan sumber daya manusia berupaya untuk mengembangkan pengetahuan, pengalaman, keahlian, produktivitas, serta kepuasan karyawan (Werner dan DeSimone, 2011 hlm. 4). Pengembangan sumber daya manusia dapat diartikan sebagai seperangkat kegiatan yang sistematis dan terencana yang dirancang oleh suatu organisasi untuk memberikan anggotanya kesempatan mempelajari keterampilan yang diperlukan untuk memenuhi tuntutan pekerjaan saat ini dan masa depan. Price ( $2011 \mathrm{hlm}$. 455) menyebutkan bahwa pengembangan sumber daya manusia merupakan pendekatan strategis untuk melakukan investasi dalam sumber daya manusia. Pengembangan sumber daya manusia menyediakan kerangka kerja untuk pengembangan diri, program pelatihan dan kemajuan karir yang disesuaikan dengan kebutuhan keterampilan dalam organisasi di masa yang akan datang. Pengembangan sumber daya manusia adalah proses untuk meningkatkan kemampuan sumber daya manusia dalam membantu tercapainya tujuan organisasi (Bangun, $2012 \mathrm{hlm}$. 5). Menurut Priansa (2014 hlm. 146), pengembangan sumber daya manusia dapat dipahami sebagai penyiapan individu karyawan untuk memikul tanggung jawab yang berbeda atau lebih tinggi di dalam organisasi. Pengembangan biasanya berhubungan dengan peningkatan kemampuan intelektual atau emosional yang diperlukan untuk menunaikan pekerjaan yang lebih baik. Pengembangan sumber daya manusia merupakan sebuah bagian dari sistem manajemen sumber daya manusia, di dalamnya termasuk pelatihan dan pengembangan (training and development), pengembangan karir (career development), dan program serta proses dari pengembangan organisasi (organization development) (Werner dan DeSimone, 2011 hlm. 10).

\section{Produktivitas Kerja}

Setiap organisasi selalu berusaha agar pegawai bisa berprestasi dalam bentuk memberikan produktivitas kerja yang maksimal. Produktivitas kerja bagi suatu organisasi sangatlah penting sebagai alat pengukur keberhasilan dalam pencapaian tujuan. Produktivitas kerja bukan hanya ditujukan untuk mendapatkan hasil kerja sebanyak-banyaknya, melainkan kualitas produktivitas juga penting diperhatikan. Secara umum produktivitas adalah ukuran efisiensi produktif suatu perbandingan antara hasil keluaran dan masuk atau output-input (Sinungan, 2003 hlm. 12). Masukan sering 
dibatasi dengan masukan tenaga kerja, sedangkan keluaran diukur dalam kesatuan fisik bentuk dan nilai.

Produktivitas adalah hubungan kerja antara jumlah produk yang dihasilkan dengan jumlah sumber daya yang diperlukan untuk menghasilkan produk tersebut atau dengan rumusan umum yang lebih rasio antara keputusan kebutuhan dan pengorbanan yang diberikan (Ravianto, $2001 \mathrm{hlm}$. 2). Sedarmayanti (2001 hlm. 57) mengutarakan bahwa produktivitas adalah bagaimana menghasilkan atau meningkatkan hasil barang dan jasa setinggi mungkin dengan memanfaatkan sumber daya secara efisien. Produktivitas adalah perbandingan antara output (hasil) dan input (masukan). Jika produktivitas naik ini hanya mungkin oleh adanya peningkatan efisiensi (waktu, bahan, tenaga) dan sistem kerja, teknik produksi dan adanya peningkatan keterampilan dan tenaga kerja (Hasibuan, $1990 \mathrm{hlm}$. 41). Oleh karena itu dapat digambarkan theoretical framework sebagai berikut:

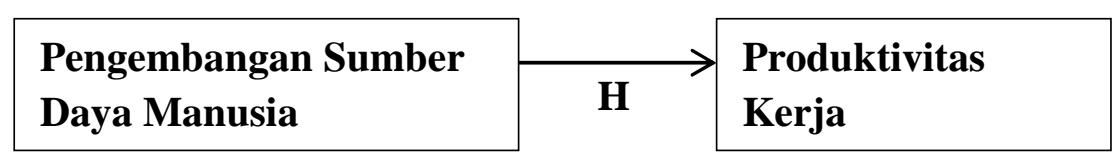

Gambar 1.

\section{Theoretical Framework}

Dari theoretical framework tersebut, penelitian ini memiliki hipotesis yaitu:

$\mathrm{H}=$ terdapat pengaruh pengembangan sumber daya manusia terhadap produktivitas kerja.

\section{METODOLOGI}

Penelitian ini dilakukan dengan tujuan untuk melihat gambaran dan dampak dari pengembangan sumber daya manusia terhadap produktivitas kerja. Metode yang digunakan dalam penelitian adalah metode explanatory survey, dengan responden sebanyak 57 orang pegawai Dinas Pendidikan Kota Bandung.

Data dikumpulkan menggunakan teknik pengumpulan melalui penyebaran angket dengan skala rating scale. Ada dua bagian angket yang diujikan kepada responden, bagian pertama ditujukan untuk mengukur pengembangan sumber daya manusia yang dijabarkan melalui lima indikator, yaitu tujuan pengembangan, para pelatih, metode pengembangan, materi pengembangan dan peserta pengembangan sebanyak 15 item. Bagian kedua ditujukan untuk mengukur produktivitas kerja yang dijabarkan melalui empat indikator, yaitu kuaitas kerja, kuantitas kerja, disiplin kerja dan kerja lembur sebanyak 12 item.

Teknik analisis statistik yang digunakan dalam mengolah data adalah teknik analisis deskriptif dan teknik analisis inferensial. Statistik deskriptif digunakan untuk menampilkan gambaran tingkat tentang pandangan responden mengenai pengembangan sumber daya manusia dan produktivitas kerja yang digambarkan dalam bentuk skor rata-rata. Statistik inferensial digunakan untuk melihat dampak dari pengembangan sumber daya manusia terhadap produktivitas kerja serta untuk menguji hipotesis yang diuji menggunakan regresi sederhana dan uji hipotesis. 


\section{HASIL PENELITIAN DAN PEMBAHASAN}

\section{Pengembangan sumber daya manusia}

Skor rata-rata yang diperoleh dari responden mengenai variabel pengembangan sumber daya manusia mencapai 3,43. Ini menunjukan bahwa variabel pengembangan sumber daya manusia dikategorikan efektif. Tabel dibawah ini menyajikan skor ratarata dari masing-masing indikator yang dijadikan ukuran pengembangan sumber daya manusia.

Tabel 1.

Kecenderungan Jawaban Responden Variabel Pengembangan Sumber Daya Manusia (X)

\begin{tabular}{|c|c|c|c|}
\hline Indikator & Item & Rata-rata & Penafsiran \\
\hline Tujuan pengembangan & $1-4$ & 3.80 & Efektif \\
\hline Para pelatih & $5-7$ & 3.02 & Cukup efektif \\
\hline Materi pengembangan & $8-10$ & 3.61 & Efektif \\
\hline Metode pengembangan & $11-13$ & 3.51 & Efektif \\
\hline Peserta pengembangan & 14-15 & 3.00 & Cukup efektif \\
\hline \multicolumn{2}{|c|}{ Rata-rata } & 3,43 & Efektif \\
\hline
\end{tabular}

Skor tertinggi pada variabel pengembangan sumber daya manusia berada pada indikator tujuan pengembangan yaitu sebesar 3,80 pada kategori efektif. Skor terendah indikator peserta pengembangan yaitu sebesar 3,00 pada kategori cukup efektif. Sehingga skor rata-rata pada variabel pengembangan sumber daya manusia 3,43 atau berada pada kategori efektif.

\section{Produktivitas Kerja}

Skor rata-rata yang diperoleh dari responden mengenai variabel produktivitas kerja mencapai 3,39. Ini menunjukan bahwa variabel produktivitas kerja dikategorikan sedang. Tabel di bawah ini menyajikan skor rata-rata dari masing-masing indikator yang dijadikan ukuran produktivitas kerja.

Tabel 2.

Kecenderungan Jawaban Responden Variabel Produktivitas Kerja (Y)

\begin{tabular}{|l|c|c|c|}
\hline \multicolumn{1}{|c|}{ Indikator } & Item & Rata-rata & Penafsiran \\
\hline Kualitas Kerja & $1-4$ & 3.57 & Tinggi \\
\hline Kuantitas Kerja & $5-8$ & 3.52 & Tinggi \\
\hline Disiplin Kerja & $9-10$ & 3.24 & Sedang \\
\hline Kerja Lembur & $11-12$ & 2.90 & Sedang \\
\hline \multicolumn{2}{|c|}{ Rata-rata } & $\mathbf{3 . 3 9}$ & Sedang \\
\hline
\end{tabular}

Skor tertinggi pada variabel pengembangan sumber daya manusia berada pada indikator kualitas kerja yaitu sebesar 3,57 pada kategori tinggi. Skor terendah indikator 
peserta pengembangan yaitu sebesar 2,90 pada kategori sedang. Sehingga skor rata-rata pada variabel produktivitas kerja 3,39 atau berada pada kategori sedang.

\section{Pengaruh pengembangan sumber daya manusia terhadap produktivitas kerja}

Untuk melihat pengaruh antara variabel pengembangan sumber daya manusia terhadap produktivitas kerja maka dianalisis dengan statistik inferensial menggunakan perhitungan analisis regresi sederhana. Diperoleh persamaan regresi sederhana Ý = $17.997+0.441(\mathrm{X})$. Tanda positif $(+)$ menunjukkan hubungan antara variabel bebas dengan variabel terikat berjalan satu arah, yang artinya setiap peningkatan atau penurunan di satu variabel, akan diikuti oleh peningkatan atau penurunan di satu variabel lainnya, sehingga apabila semakin tinggi pengembangan sumber daya manusia, maka semakin tinggi pula produktivitas kerja pegawai begitupun sebaliknya.

Berdasarkan perhitungan pengujian hipotesis diperoleh $F_{\text {hitung sebesar 24,236 }}$ sedangkan $\mathrm{F}_{\text {tabel }}$ dengan tingkat kesalahan $\alpha=0,05$ dan dan dk reg b/a $=1$ dan dk res $=$ $n-2=55$ sebesar 4,016, artinya $F_{\text {hitung }}>F_{\text {tabel }}$ yaitu 24,236>4,016. Dapat disimpulkan bahwa "terdapat pengaruh positif dan signifikan antara pengembangan sumber daya manusia terhadap produktivitas kerja pegawai di Dinas Pendidikan Kota Bandung”.

Nilai koefisien determinasi variabel pengembangan sumber daya manusia dan variabel produktivitas kerja sebesar $31 \%$. Artinya, secara parsial pengembangan sumber daya manusia memiliki dampak terhadap produktivitas kerja sebesar $31 \%$. Sisanya sebesar $69 \%$ dipengaruhi oleh faktor lain.

\section{KESIMPULAN}

Indikator pengembangan sumber daya manusia meliputi tujuan pengembangan berada pada kategori efektif, para pelatih berada pada kategori cukup efektif, materi pengembangan berada pada kategori efektif, metode pengembangan berada pada kategori efektif dan peserta pengembangan berada pada kategori cukup efektif. Indikator produktivitas kerja meliputi kualitas kerja berada pada tinggi, kuantitas berada pada kategori tinggi, disiplin kerja berada pada kategori sedang dan kerja lembur berada pada kategori sedang.

Terdapat pengaruh positif dan signifikan antara pengembangan sumber daya manusia terhadap produktivitas kerja pegawai. Demikian pula halnya dengan korelasi antara pengembangan sumber daya manusia terhadap produktivitas kerja pegawai memiliki korelasi yang sedang. Dengan demikian rekomendasi yang dapat diambil dalam upaya meningkatkan produktivitas kerja adalah perlu adanya peningkatan pengetahuan, keterampilan dan motivasi pegawai dalam mengikuti program pengembangan maupun dalam bekerja, sehingga produktivitas kerja akan diperoleh secara optimal.

\section{DAFTAR PUSTAKA}

Bangun, W. 2012. Manajemen Sumber Daya Manusia. Jakarta: Erlangga.

Hasibuan, M.P. 1990. Manajeman Sumber Daya Manusia, Dasar dan Kunci Keberhasilan. Jakarta: Toko Gunung Agung.

Hasibuan, M.P. 2007. Manajeman Sumber Daya Manusia. Jakarta: cetakan 9. Toko Gunung Agung.

Mathis, R.L. \& Jackson, J.H. 2006. Manajemen Sumber Daya Manusia. Jakarta: Salemba Empat. 
Price. 2011. Human Resource Development. Fourth Edition. South Western. Nelson Education Ltd.

Priansa, D.J. 2014. Perencanaan \& Pengembangan SDM. Penerbit Bandung: Alfabeta

Ravianto, J. 2001, Produktivitas dan Pengukuran. Binaman Aksara, Jakarta.

Richard A. \& Elwood F. 2001. Foundation of Human Resource Development. San

Fransisco: Berrett-Koehler Publisher, Inc.

Rowley, C. \& Jackson, K. 2012. Manajemen Sumber Daya Manusia The Key Concepts, Cetakan Kesatu, PT Rajagrafindo Persada, Jakarta.

Sumarsono, S. 2003. Ekonomi Manajemen Sumber Daya Manusia dan Ketenagakerjaan. Yogyakarta: Graha Ilmu

Sinungan, M. (2003). Produktivitas Apa dan Bagaimana. Bandung: Bumi Aksara.

Sedarmayanti. 2001. Sumber Daya Manusia dan Produktivitas Kerja. Bandung: Mandar Maju.

Werner, J.M. \& DeSimone, R.L. 2011. Human Resource Development. Sixth Edition. South Western. Nelson Education Ltd. 